\title{
The negative association between total ghrelin levels, body mass and insulin secretion is lost in hypercortisolemic patients with Cushing's disease
}

Roberta Giordano, Andrea Picu, Uberto Pagotto ${ }^{1}$, Rosaria De Iasio ${ }^{1}$, Lorenza Bonelli, Flavia Prodam, Fabio Broglio, Lisa Marafetti, Renato Pasquali ${ }^{1}$, Mauro Maccario, Ezio Ghigo and Emanuela Arvat

Division of Endocrinology and Metabolism, Department of Internal Medicine, University of Turin, Turin, Italy ${ }^{1}$ Endocrinology Unit and Center for Applied Biomedical Research, Department of Internal Medicine and Gastroenterology, University of Bologna, Bologna, Italy

(Correspondence should be addressed to E Arvat; Email: emanuela.arvat@unito.it)

\begin{abstract}
Objective: Ghrelin exerts a wide spectrum of endocrine and non-endocrine actions. The stomach is the major source of circulating ghrelin levels that are negatively associated with body mass, insulin and glucose levels. The role of glucocorticoids in ghrelin secretion and action is still unclear.

Design: In 8 patients with Cushing's disease (CD, BMI $\left.29.8 \pm 1.6 \mathrm{~kg} / \mathrm{m}^{2}\right), 7$ normal (NS) and 6 obese subjects (OB, BMI $32.9 \pm 1.1 \mathrm{~kg} / \mathrm{m}^{2}$ ) we studied: a) total ghrelin levels (every $15 \mathrm{~min}$ over $3 \mathrm{~h}$ ) and their correlation with BMI, insulin, glucose, homeostatic model assessment (HOMA) index, ACTH and cortisol levels; b) GH, ACTH, cortisol, insulin and glucose responses to acylated ghrelin administration $(1.0 \mu \mathrm{g} / \mathrm{kg}$ i.v. at $0 \mathrm{~min})$.

Results: CD patients had BMI, insulin and glucose levels as well as HOMA index higher than those in NS $(P<0.05)$ but similar to those in OB. Despite this, total ghrelin levels in CD were similar to those in NS and both were higher $(P<0.05)$ than those in OB. No correlation was found among total ghrelin and BMI, insulin, glucose, ACTH and cortisol levels in CD patients. The GH responses to ghrelin in $\mathrm{CD}$ and $\mathrm{OB}$ were similar and both were lower $(P<0.002)$ than those in NS. In CD ghrelin induced exaggerated ACTH and cortisol responses clearly higher $(P<0.005)$ than in OB and NS. Ghrelin administration increased glucose in all groups; insulin levels showed slight decrease that was significant $(P<0.05)$ in $\mathrm{OB}$ only.

Conclusions: Hypercortisolism in humans is associated with impaired ghrelin secretion and action. In fact, total ghrelin secretion in CD is not reduced despite increased BMI, insulin and glucose levels, while the GH and ACTH responses to acylated ghrelin are clearly reduced and enhanced, respectively.
\end{abstract}

European Journal of Endocrinology 153 535-543

\section{Introduction}

The stomach is the major source of ghrelin secretion, although it is also expressed in several other central and peripheral tissues including bowel and pancreas $(1,2)$. Ghrelin has been discovered as natural ligand of the orphan GH secretagogue receptor (GHS-R) type $1 \mathrm{a}$, whose expression is concentrated in the hypothalamo-pituitary unit but also in other central and peripheral tissues, including the pancreas $(3,4)$. The widespread distribution of ghrelin and GHS-R expression agrees with the wide spectrum of endocrine and non-endocrine ghrelin actions $(2,5)$; indeed, ghrelin is much more than a natural GHS. At present, there is evidence suggesting that, among the most important ghrelin actions, there are central effects on appetite, energy balance, and peripheral metabolic effects on insulin secretion, glucose and lipid metabolism (2, 6-8). Ghrelin secretion in humans undergoes important fluctuations during the day (9), it is stimulated by energy restriction and acetylcholine, while it is inhibited by somatostatin, insulin and glucose load $(7,10-13)$. Above all, it has been clearly demonstrated that ghrelin secretion is negatively correlated with body mass index (BMI) and insulin secretion; in fact, total ghrelin levels are increased in anorexia and cachexia while they are markedly reduced in obesity (14-20). In contrast to the body of information on the relationship between ghrelin and energy balance, the role of glucocorticoids on ghrelin secretion and action is still unclear. The marked impact of glucocorticoids on insulin and glucose metabolism as well as on GH secretion and body composition is well known. In fact, hyperinsulinism, insulin resistance and glucose 
intolerance up to secondary diabetes mellitus, as well as marked GH insufficiency, are hallmarks of Cushing's syndrome, that is classically connoted by visceral adiposity and central obesity (21). Regarding ghrelin actions, it has already been reported that Cushing's disease (CD) is associated to unexpected ACTH and cortisol hyperresponsiveness coupled with reduced GH response to ghrelin as well as to synthetic GHS (22-24). Regarding ghrelin secretion and its metabolic actions as a function of glucocortioid status, it has recently been reported in a group of patients with $\mathrm{CD}$ that ghrelin levels, evaluated as single morning measurements, were lower than in normal controls, confirming previous data (25), but increased after successful transsphenoidal surgery, despite similar glucose and insulin levels (26).

In order to further clarify the relationship between ghrelin and glucocorticoid status, we studied ghrelin secretion as a function of several anthropometric and metabolic parameters, as well as the endocrine and metabolic response to acylated ghrelin, in patients with pituitary adrenocorticotropic hormone (ACTH)dependent Cushing's syndrome in comparison to a group of normal or obese age-matched controls.

\section{Subjects and methods}

\section{Subjects}

Eight patients with $\mathrm{CD}(\mathrm{CD}, 8 \mathrm{~F}, 37.5 \pm 2.1$ years, BMI $29.8 \pm 1.6 \mathrm{~kg} / \mathrm{m}^{2}$ ) were studied; these were all CD patients who have not been studied before. The diagnosis of $\mathrm{CD}$ was made by international criteria including: high levels of urinary free cortisol, normal or high plasma ACTH and serum cortisol levels, absent suppression of cortisol after low-dose dexamethasone test and adequate suppression of cortisol after a high-dose dexamethasone test. In 3 cases (cases 5, 6 and 8) inferior petrosal venous sinus sampling has also been performed, indicating the existence of a pituitary ACTH-dependent Cushing's syndrome. Based on hormonal and MRI findings, CD patients were diagnosed as having: a) pituitary ACTHsecreting microadenoma (cases 1-3), b) pituitary ACTH-secreting macroadenoma (cases 4 and 7), c) pituitary ACTH-dependent Cushing's syndrome with normal MRI (cases 5, 6 and 8), all patients showed no evidence of hypopituitarism. Two CD patients had normal glucose tolerance $(\mathrm{N})$, four patients showed impaired glucose tolerance (IGT) and two patients had Type 2 diabetes (DMII), respectively. None of the patients were taking medical treatment what would influence hormonal secretion during the test period. Clinical details of the patients are reported in Table 1. In five patients the diagnosis of ACTH-secreting pituitary adenoma was confirmed by immunostaining after transsphenoidal surgery; three other patients refused surgery and were on medical treatment. Seven normal lean subjects (NS, $7 \mathrm{~F}, 30.6 \pm 8.0$ years, BMI $20.3 \pm 1.7 \mathrm{~kg} / \mathrm{m}^{2}$ ) and six subjects with simple obesity (OB, 6 F, $42.2 \pm 5.1$ years, BMI $32.9 \pm 1.1 \mathrm{~kg} / \mathrm{m}^{2}$, waist circumference $102.2 \pm 7.0 \mathrm{~cm}$ ) were studied as control groups in their early follicular phase. The study had been approved by the Ethical Committee of the University of Turin and informed consent was obtained from all subjects. All subjects underwent the following two testing sessions, in randomized order with at least three days apart: 1) saline $(250 \mathrm{ml}$ infused for $180 \mathrm{~min}) ; 2$ ) ghrelin $(1.0 \mu \mathrm{g} / \mathrm{kg}$ acylated ghrelin i.v. bolus at $0 \mathrm{~min})$. The testing sessions started between $0830 \mathrm{~h}$ and $0900 \mathrm{~h}$ after an overnight fast and $30 \mathrm{~min}$ after venous cannulation, kept patent by slow infusion of isotonic saline. All samples from individual subjects were analyzed together.

\section{Assay}

Blood samples were taken every 15 min from 0 up to $180 \mathrm{~min}$ (session 1) and from -15 up to $90 \mathrm{~min}$ (session 2). In session 1, total ghrelin, insulin and glucose levels were assayed at each time point, and HOMA index was calculated. In session 2, GH, ACTH, cortisol, insulin and glucose were assayed at each time point. Plasma

Table 1 Clinial and hormonal details of the patients with Cushing's disease.

\begin{tabular}{|c|c|c|c|c|c|c|c|c|}
\hline Case & Sex & Age (years) & BMI $\left(\mathrm{kg} / \mathrm{m}^{2}\right)$ & UFC $(\mu \mathrm{g} / 24 \mathrm{~h})$ & ACTH (pg/ml) & Cortisol $(\mu \mathrm{g} / \mathrm{l})$ & Glycemic State & MRI imaging \\
\hline 1 & $\mathrm{~F}$ & 31 & 21 & 216 & 76.2 & 202.8 & DM II & micro adenoma \\
\hline 2 & $\mathrm{~F}$ & 29 & 35 & 183 & 88.6 & 258.8 & DM II & micro adenoma \\
\hline 3 & $\mathrm{~F}$ & 42 & 31 & 418 & 65.6 & 227.2 & IGT & micro adenoma \\
\hline 4 & $\mathrm{~F}$ & 43 & 35 & 109 & 54.0 & 133.3 & IGT & macro adenoma \\
\hline 5 & $\mathrm{~F}$ & 41 & 28 & 194 & 88.0 & 170.4 & IGT & normal \\
\hline 6 & $\mathrm{~F}$ & 42 & 31 & 112 & 55.3 & 290.1 & $\mathrm{~N}$ & normal \\
\hline 8 & $\mathrm{~F}$ & 41 & 27 & 497 & 34.2 & 191.7 & $\mathrm{~N}$ & normal \\
\hline Mean士s.E.M. & & $37.5 \pm 2.1$ & $29.8 \pm 1.6$ & $340.1 \pm 105.4$ & $72.2 \pm 9.4$ & $214.0 \pm 17.7$ & & \\
\hline
\end{tabular}

UFC, urinary free cortisol (mean of two measurements; $2.75 \mu \mathrm{g} / 24 \mathrm{~h}=1 \mathrm{nmol} /$ day).

ACTH plasma concentrations at $09.00 \mathrm{~h}$ (mean of two measurements; $0.22 \mathrm{pg} / \mathrm{ml}=1 \mathrm{pmol}$ ).

Cortisol serum concentrations at $09.00 \mathrm{~h}$ (mean of two measurements; $2.7 \mu \mathrm{g} / \mathrm{l}=1 \mathrm{nmol} / \mathrm{l}$ ).

N, normal; IGT, impaired glucose tolerance; DMII, Type II diabetes. 
total ghrelin levels $(\mathrm{pg} / \mathrm{ml})$ were assayed in duplicate for immunoreactive ghrelin concentration, by a commercially available RIA (Phoenix Pharmaceuticals, Mountain View, CA, USA) using ${ }^{125}$ I-labeled bioactive ghrelin as a tracer and a rabbit polyclonal antibody raised against the $\mathrm{C}$-terminus of human ghrelin. This assay recognizes both acylated and deacylated ghrelin. The antiserum does not cross-react with any relevant peptide as previously shown. Intra- and inter-assay CV were below $5.3 \%$ and $13.6 \%$, respectively. Serum insulin levels $\quad(\mathrm{mU} / \mathrm{l} ; \quad 1 \mathrm{mU} / \mathrm{l} \times 7.175=1 \mathrm{pmol} / \mathrm{l}) \quad$ were measured in duplicate by immunoradiometric assay (INSIK-5, Sorin Biomedica, Saluggia, Italy). The sensitivity of the assay was $2.5 \mathrm{mU} / \mathrm{l}$. The inter- and intraassay CV ranged from 6.2 to $10.8 \%$ and from 5.5 to $10.6 \%$, respectively. Plasma glucose levels $(\mathrm{mg} / \mathrm{dl}$; $1 \mathrm{mg} / \mathrm{dl} \times 0.05551=1 \mathrm{mmol} / \mathrm{l})$ were measured by glucose-oxidase colorimetric method (Glucofix, Menarini Diagnostici, Florence, Italy). HOMA index was calculated with the formula: serum insulin $(\mathrm{mU} / \mathrm{l}) \times$ plasma glucose $(\mathrm{mmol} / \mathrm{l})$ 122.5. Plasma ACTH levels $(\mathrm{pg} / \mathrm{ml}$; $1 \mathrm{pg} / \mathrm{ml} \times 0.2202=1 \mathrm{pmol} / \mathrm{l})$ were measured in duplicate by immunoradiometric assay (Allegro HS-ACTH, Nichols Institute Diagnostics, San Juan Capistrano, CA, USA). The sensitivity of the assay was $1 \mathrm{pg} / \mathrm{ml}$. The inter- and intra-assay CV ranged from 6.9 to $8.9 \%$ and from 1.1 to $3.0 \%$, respectively. Serum cortisol levels $(\mu \mathrm{g} / \mathrm{l} ; 1 \mu \mathrm{g} / \mathrm{l} \times 27.59=1 \mathrm{nmol} / \mathrm{l})$ were measured in duplicate by RIA (CORT-CTK 125 RIA; Sorin Biomedica). The sensitivity of the assay was $0.4 \mu \mathrm{g} / \mathrm{l}$. The inter- and intra-assay CV ranged from 6.6 to $7.5 \%$ and from 3.8 to $6.6 \%$ respectively. Serum GH levels $(\mu \mathrm{g} / \mathrm{l})$ were measured in duplicate by immunoradiometric assay (hGH-CTK IRMA, Sorin Biomedica). The sensitivity of the assay was $0.15 \mu \mathrm{g} / \mathrm{l}$. The inter-and intraassay CV ranged from $2.9-4.5 \%$ and from $2.4-4.0 \%$, respectively. The hormonal responses are expressed as mean \pm S.E.M of absolute levels or areas under curves (AUC) calculated by trapezoidal integration.

\section{Statistical analysis}

The statistical analysis was carried out using non-parametric ANOVA (Friedman or Kruskall-Wallis test) and then Wilcoxon matched pairs test or Mann-Whitney U test as appropriate; correlations were carried out using the Spearman correlation coefficient. Results are expressed as mean \pm s.E.M.

\section{Results}

BMI in CD (mean \pm s.E.M.: $29.8 \pm 1.6 \mathrm{~kg} / \mathrm{m}^{2}$ ) was higher $(P<0.05)$ than in NS $\left(20.3 \pm 1.7 \mathrm{~kg} / \mathrm{m}^{2}\right)$, but similar to that in $\mathrm{OB}\left(32.9 \pm 1.1 \mathrm{~kg} / \mathrm{m}^{2}\right)$. At baseline, HOMA index in $\mathrm{CD}(3.9 \pm 1.4)$ was similar to that in $\mathrm{OB}(3.7 \pm 0.9)$ and both were higher $(P<0.05)$ than in NS $(2.5 \pm 0.4)$. During saline infusion, insulin and glucose levels in CD
$(2808.4 \pm 230.3 \mathrm{mU} / \mathrm{l}$ per $\mathrm{h}$ and $14637.5 \pm 402.9 \mathrm{mg} / \mathrm{dl}$ per $\mathrm{h}$, respectively) were higher $(P<0.05)$ than in NS (2194.0 $\pm 74.2 \mathrm{mU} / \mathrm{l}$ per $\mathrm{h}$ and $13768.5 \pm 195.5 \mathrm{mg} / \mathrm{dl}$ per $\mathrm{h}$, respectively). but similar to those in OB. (3223.5 $\pm 255.9 \mathrm{mU} / \mathrm{l}$ per $\mathrm{h}$ and $14983.5 \pm 382.7 \mathrm{mg} / \mathrm{dl}$ per h, respectively) (Fig. 1). Total ghrelin levels in CD $(121650.0 \pm 13549.3 \mathrm{pg} / \mathrm{ml}$ per $\mathrm{h}$ ) were more similar to those in NS (125775.0 $\pm 12194.3 \mathrm{pg} / \mathrm{ml}$ per $\mathrm{h})$ and both were higher $(P<0.05)$ than in $\mathrm{OB}$ $(96840.0 \pm 6327.9 \mathrm{pg} / \mathrm{ml}$ per h)(Fig. 2). In contrast to $\mathrm{OB}$, total ghrelin levels in $\mathrm{CD}$ did not correlate with BMI, insulin and glucose levels as well as HOMA index. Moreover, no correlation was found between total ghrelin, ACTH and cortisol levels in CD. The acute administration of acylated ghrelin induced a $\mathrm{GH}$ response in $\mathrm{CD}$ similar to that in OB $(900.8 \pm 285.2$ vs $1317.9 \pm 294.0 \mu \mathrm{g} / \mathrm{l}$ per $\mathrm{h})$ and both were lower $(P<0.002)$ than that in NS $(4618.2 \pm 558.4 \mu \mathrm{g} / \mathrm{l}$ per $\mathrm{h})$. On the other hand, ACTH and cortisol responses to ghrelin in CD $(16439.6 \pm 2274.2 \mathrm{pg} / \mathrm{ml}$ per $\mathrm{h}$ and $27677.4 \pm 1838.4 \mu \mathrm{g} / \mathrm{l}$ per $\mathrm{h}$, respectively) were clearly higher $(P<0.005)$ than in OB $(3910.6 \pm$ $971.2 \mathrm{pg} / \mathrm{ml}$ per $\mathrm{h}$ and $17193.6 \pm 1508.0 \mu \mathrm{g} / \mathrm{l}$ per $\mathrm{h}$, respectively) and in NS $(2662.7 \pm 748.9 \mathrm{pg} / \mathrm{ml}$ and $12299.4 \pm 19212.3 \mu \mathrm{g} / \mathrm{l}$ per h, respectively). The ACTH and cortisol responses in OB and NS were in turn similar (Fig. 3). Ghrelin administration induced an increase of glucose levels in CD (7851.0 $\pm 437.6 \mathrm{mg} / \mathrm{dl}$ per h) similar to that in $\mathrm{OB}(7775.6 \pm 238.3 \mathrm{mg} / \mathrm{dl}$ per $\mathrm{h})$ and in NS (6536.1 $\pm 376.2 \mathrm{mg} / \mathrm{dl}$ per $\mathrm{h})$. The ghrelin-induced glycemic increase was coupled to a transient decrease of insulin levels in all groups although statistical significance $(P<0.05)$ was attained in OB only (Fig. 4$)$.

\section{Side effects}

After ghrelin administration, four NS, three OB and one CD patient showed transient facial flushing, whereas five NS, four $\mathrm{OB}$ and six CD reported to be hungry at the end of the testing session.

\section{Discussion}

The results of the present study demonstrate that the negative relationship linking BMI, insulin secretion and resistance with ghrelin secretion is lost in hypercortisolemic patients with CD. In fact, in comparison with weight-matched obese subjects, patients with CD with the classical increase in body mass, glucose and insulin secretion, show circulating total ghrelin levels similar to those in normal lean subjects. The insulin and glucose responses to the acute administration of acylated ghrelin in patients with $\mathrm{CD}$ basically overlaps with the responses of either lean or obese control subjects. On the other hand, the findings of the present study confirm our previous data showing that, differently from obese patients, besides reduced GH response, hypercortisolemic patients 

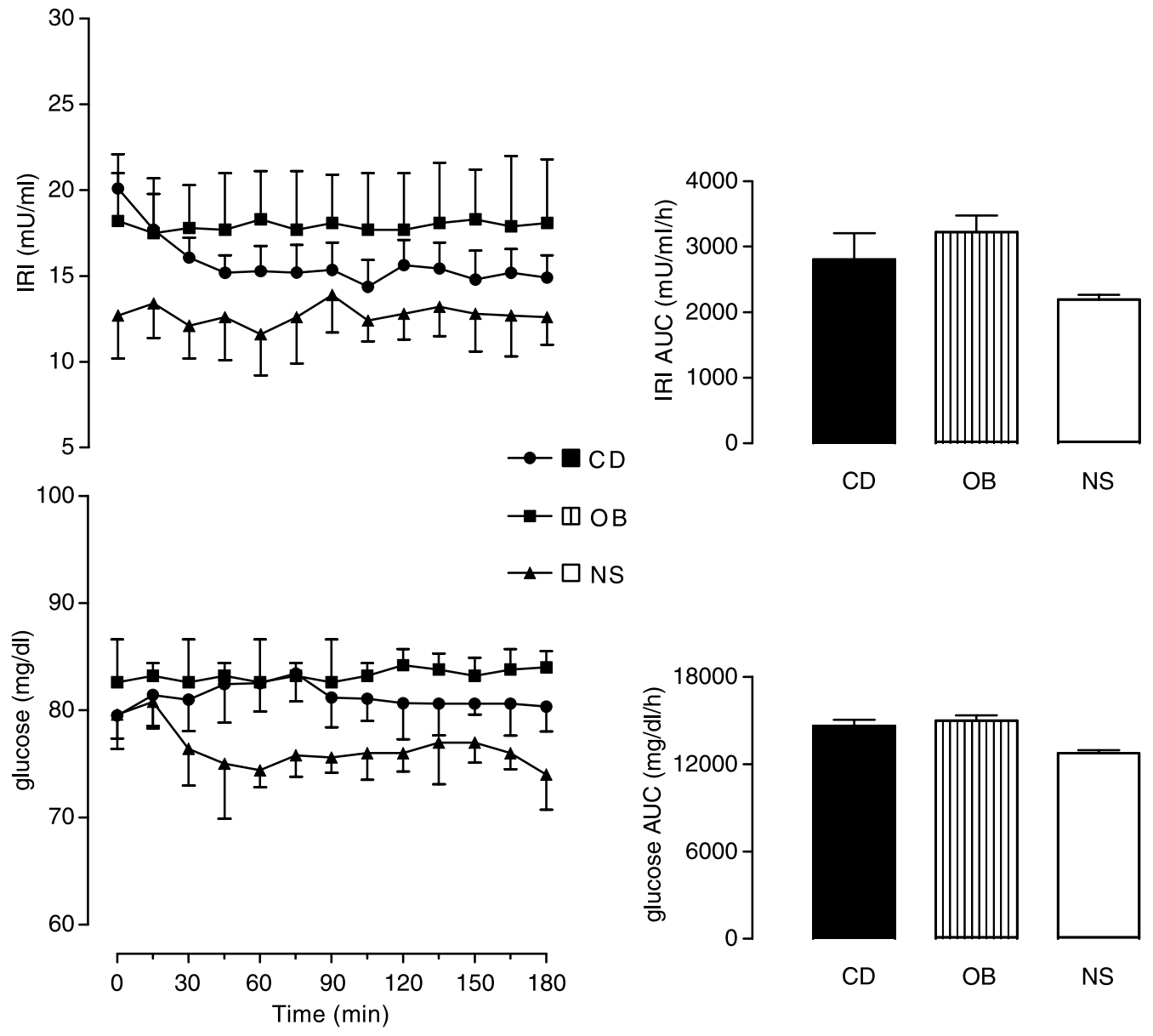

with CD also show an exaggerated ACTH and cortisol responses to ghrelin administration (24). It has been widely demonstrated that ghrelin secretion is negatively associated to BMI and insulin secretion. In fact, total

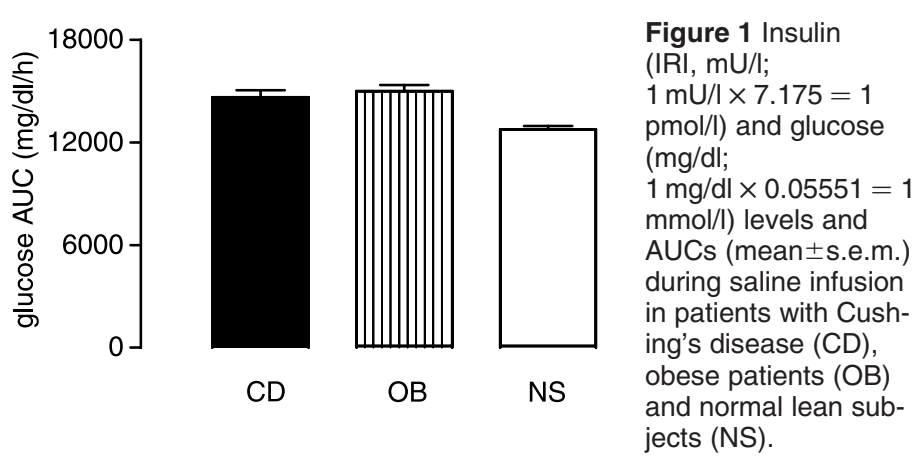

Figure 1 Insulin (IRI, mU/l; mol/l) and glucose (mg/dl; $\mathrm{mmol} / \mathrm{l}$ ) levels and s (mean + s.e.m.) Aucs (maline infusion patients with Cushobese patients $(\mathrm{OB})$ jects (NS).

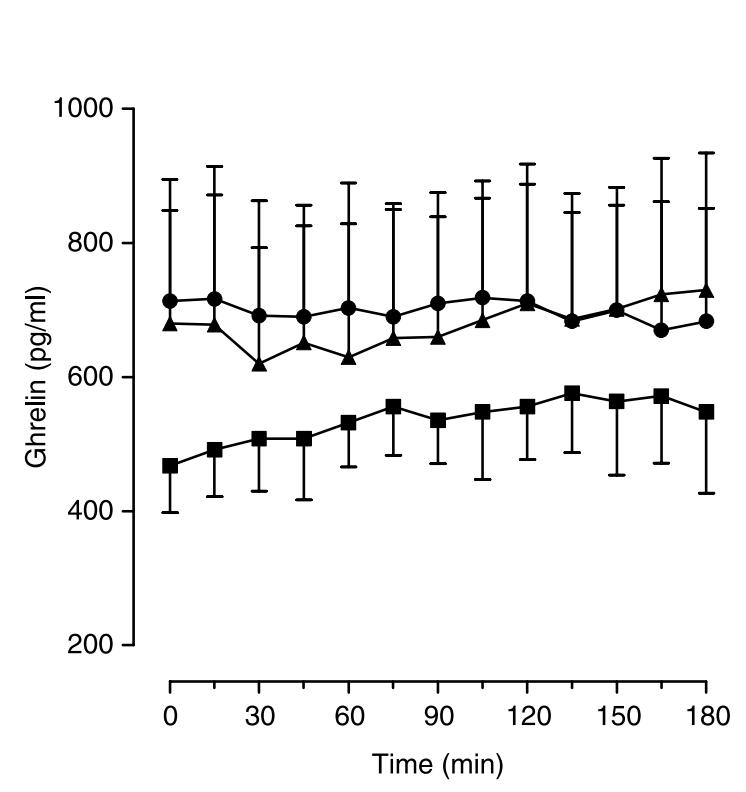

ghrelin levels are increased in anorexia and cachexia while it is markedly reduced in obesity $(14-20)$. The reduction of total ghrelin levels in obesity is also confirmed by the present study. Obesity has been reported

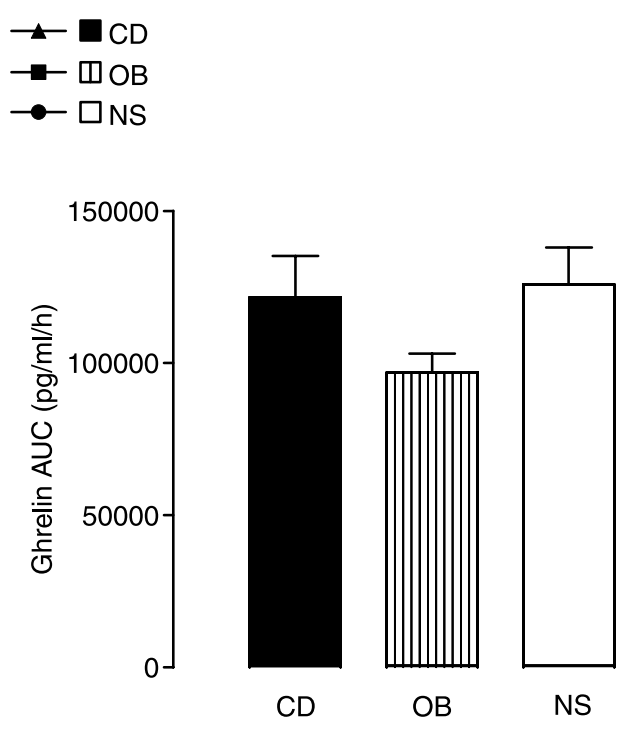

Figure 2 Total ghrelin levels and AUCs

(mean \pm S.E.M.) during saline infusion in patients with Cushing's disease (CD), obese patients $(\mathrm{OB})$ and normal lean subjects (NS). 

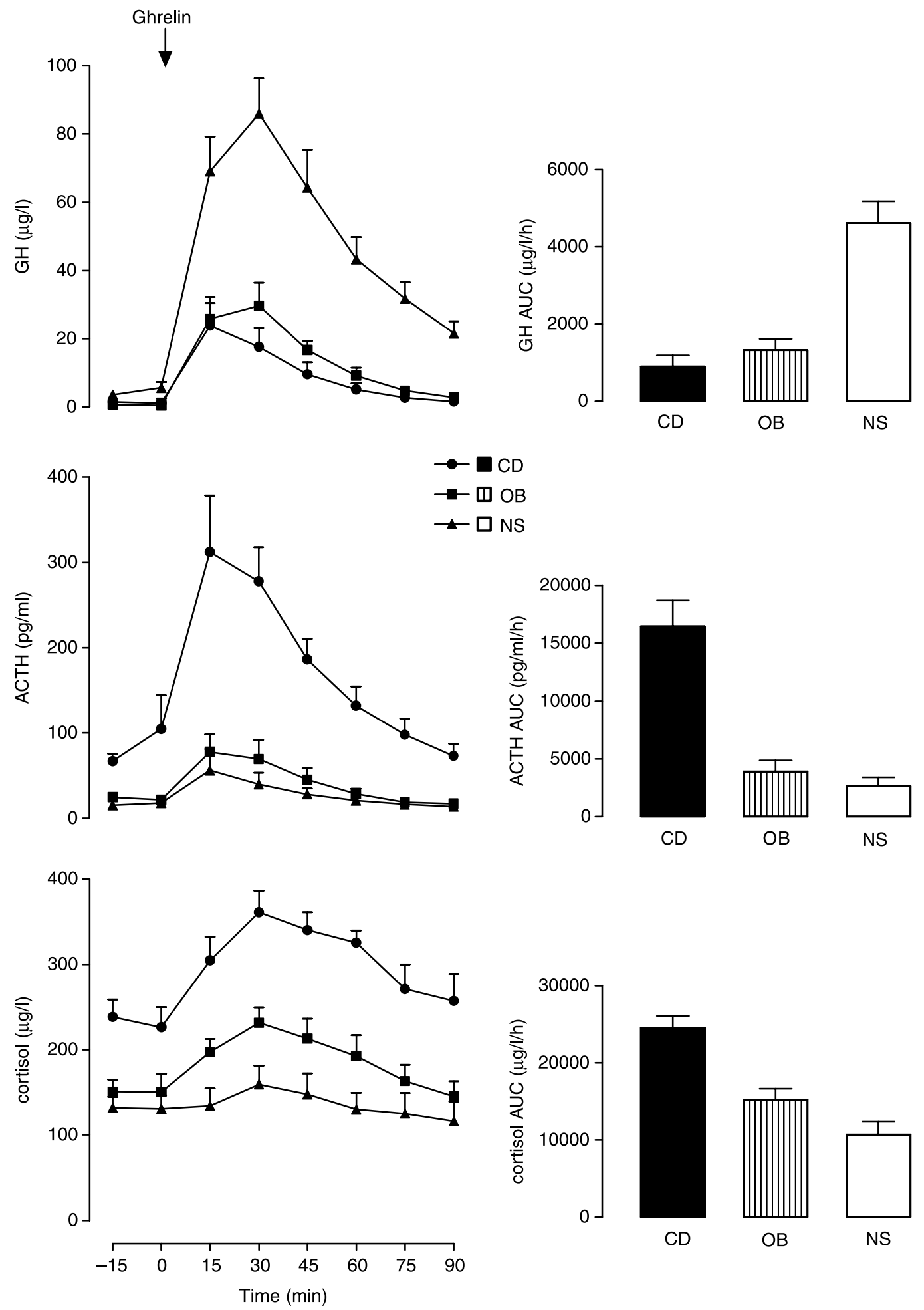

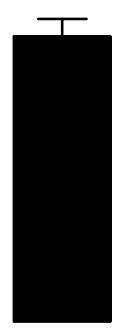

CD

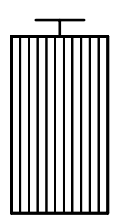

$\mathrm{OB}$

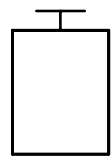

NS

Figure $3 \mathrm{GH}, \mathrm{ACTH}(\mathrm{pg} / \mathrm{ml} ; 0.22 \mathrm{pg} / \mathrm{ml}=1 \mathrm{pmol} / \mathrm{l})$ and cortisol $(\mu \mathrm{g} / \mathrm{l} ; 2.7 \mu \mathrm{g} / \mathrm{l}=1 \mathrm{nmol} / \mathrm{l})$ levels and AUCs (mean $\pm \mathrm{S}$.E.M.) after acylated ghrelin $(1.0 \mu \mathrm{g} / \mathrm{kg}$ i.v. at $0 \mathrm{~min})$ in patients with Cushing's disease (CD), obese patients (OB) and normal lean subjects (NS). 

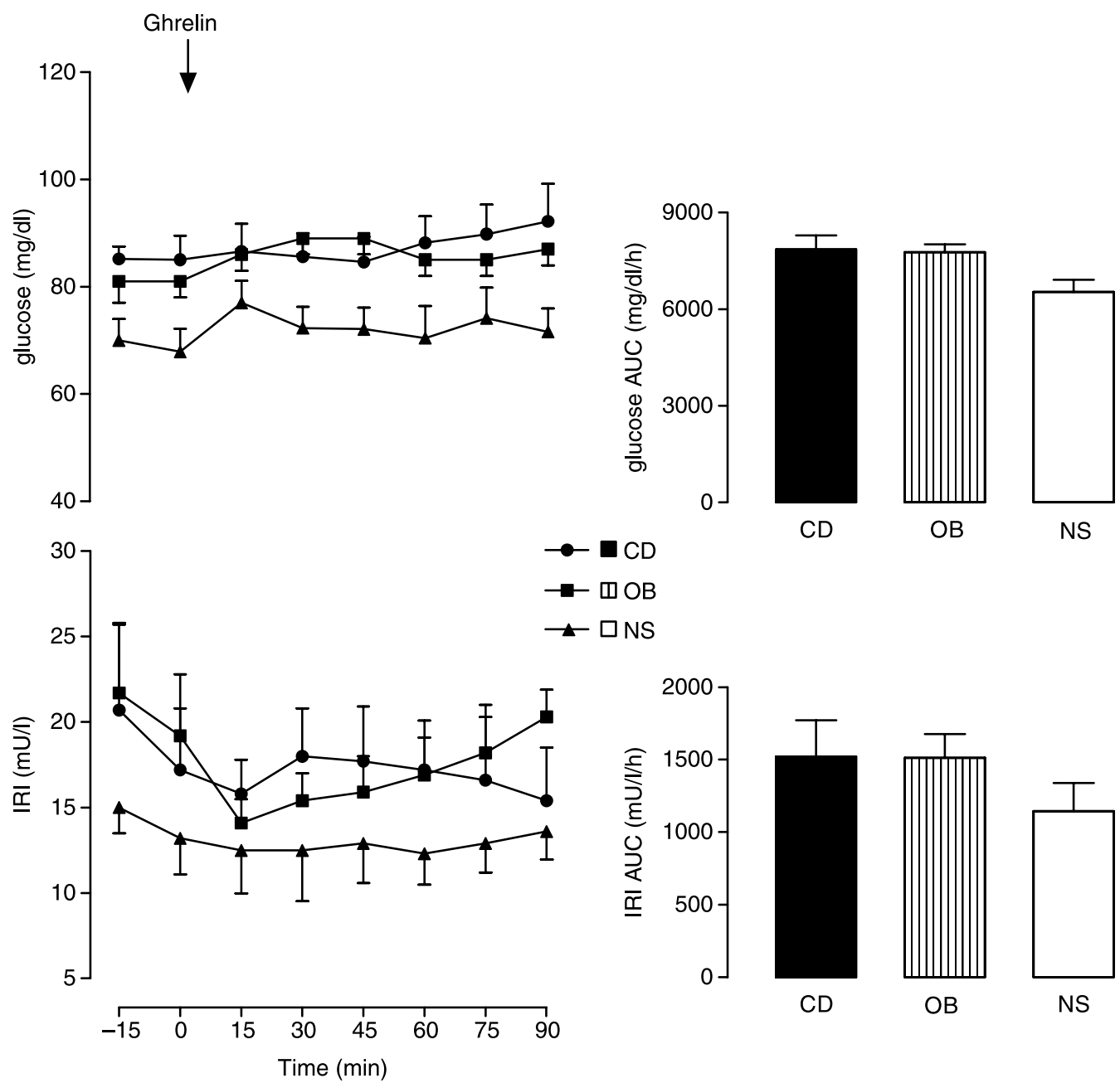

Figure 4 Glucose $(\mathrm{mg} / \mathrm{dl} ; 1 \mathrm{mg} / \mathrm{dl} \times 0.05551=1 \mathrm{mmol} / \mathrm{l})$ and insulin $(\mathrm{IRI}, \mathrm{mU} / \mathrm{l} ; 1 \mathrm{mU} / \mathrm{l} \times 7.175=1 \mathrm{pmol} / \mathrm{l})$ levels and AUCs $(\mathrm{mean} \pm$ S.E.M.) after acylated ghrelin $(1.0 \mu \mathrm{g} / \mathrm{kg}$ i.v. at $0 \mathrm{~min})$ in patients with Cushing's disease (CD), obese patients (OB) and normal lean subjects (NS).

to be connoted by some hypothalamic-pituitary-adrenal (HPA) axis hyperactivity (27) but evidence that total ghrelin levels are reduced points against any role of ghrelin in the subtle HPA derangement connoting this condition. The inhibitory action of insulin on ghrelin synthesis and secretion has been clearly demonstrated; in fact, total ghrelin levels are reduced either during euglycemic clamp studies or following insulin-induced hypoglycemia (12, 28-30). Nevertheless, ghrelin secretion has also been clearly shown to be inhibited after oral or intravenous glucose load $(15,31,32)$. Despite the mechanisms underlying the inhibitory effect of insulin and glucose on ghrelin secretion are still a matter of debate, total ghrelin levels have been found to be negatively correlated with insulin secretion and resistance as well as with glucose levels $(32,33)$. In fact, total ghrelin levels have been shown to be reduced in diabetes mellitus type 2 (34) and surprisingly in diabetes mellitus type 1 (35). This strong negative relationship linking ghrelin secretion with body mass, glucose levels, insulin secretion and resistance would logically predict ghrelin hyposecretion in hypercortisolemic states, such as CD. However, a reduction of total ghrelin levels has also been reported in other conditions connoted by insulin resistance, such as PCO syndrome (36). However, our data show that CD patients, despite their classical metabolic feature, display mean total ghrelin levels (recorded over 3 morning hours) similar to those in age-matched lean controls, but higher than those in obese patients. It has to be emphasized that CD and obese patients were comparable in terms of BMI as well as insulin and glucose levels and even the HOMA index. Therefore, this evidence points towards the hypothesis that the hypercortisolemic state is able to counteract the negative impact of hyperinsulinism, insulin resistance, increased glucose levels as well as increased body fat mass on ghrelin secretion. These data agree with previous findings that showed a lack of correlation between ghrelin, BMI, glucose, insulin secretion and resistance in $\operatorname{CD}(25,26)$. Although 
other steroids such as androgens, are supposed to play a role in the modulation of ghrelin levels (37), the role (if any) of glucocorticoids in the regulation of ghrelin synthesis and secretion is still unclear. The stimulatory effect of corticosterone on ghrelin mRNA expression at the gastric and pituitary level in rats has been reported but these findings have not been confirmed by other studies $(38,39)$. As anticipated, it has recently been reported that in patients with $\mathrm{CD}$, ghrelin levels evaluated as single morning measurements, were lower than normal controls $(25,26)$, but increased after successful trans-sphenoidal surgery, despite similar glucose and insulin levels (26). These data disagree with our present findings, but the difference in the study protocol (the evaluation of a single morning measurement instead of more prolonged observation during morning hours) could explain the discrepancy. In fact, it has been clearly demonstrated that ghrelin levels undergo marked circadian and interindividual variations (9), therefore it is a more appropriate method to observe ghrelin levels over a prolonged period of observation, as carried out in our present study. On the other hand, in agreement with our findings, Libe et al. 2005 failed to show any correlation between ghrelin, ACTH and cortisol levels, even though lower ghrelin levels has been found in their CD patients (26). Both the present study and Libe et al. 2005 show the lack of association between cortisol and ghrelin levels, this could be due to the small number of CD patients tested. Independent of the mechanisms underlying the relative ghrelin hypersecretion in hypercortisolemic states, such as $\mathrm{CD}$, the main message of this study is that the exposure of chronically elevated glucocorticoid levels are able to counteract the major metabolic inputs that influence ghrelin secretion. Again, it has to be considered that important information about the relationship linking glucocorticoids and ghrelin secretion, should come from distinguishing total from acylated circulating ghrelin levels. Besides impaired ghrelin secretion, our results show that although the negative association between ghrelin, insulin and glucose levels is lost in CD, these patients present normal insulin and glucose responses to acute acylated ghrelin, suggesting that high glucocorticoid levels, which deeply impairs glycometabolic status, do not influence the metabolic response to ghrelin administration. It has been clearly shown that ghrelin is able to exert metabolic actions, influencing insulin secretion as well as glucose and lipid metabolism $(2,6,7)$. In humans, acute ghrelin administration is followed by a transient decrease in insulin levels that is anticipated by a hyperglycemic effect $(40,41)$ and recent studies seem to indicate that these actions reflect the direct actions of ghrelin at the pancreatic, hepatic and adipose tissue level (2). In this context, our present findings suggest that the mechanisms underlying the ghrelin action on glycometabolic function are basically preserved during the chronic hypercortisolism state. On the other hand, we confirm that $\mathrm{CD}$ is associated with a decrease in somatotroph and a clear cut increase in corticotroph responsiveness to acute ghrelin administration. In fact, these findings agree with our previous studies performed with ghrelin or synthetic GHS $(22-24)$. The low GH response to ghrelin in hypercortisolemic states fits well with the generalized reduction of $\mathrm{GH}$ response to all known provocative stimuli of somatotroph secretion in CD. This is likely to reflect either pituitary or hypothalamic alterations (42, 43). Meantime, the low GH response to provocative stimuli including ghrelin in CD, a condition with surprisingly intact ghrelin secretion, is against the hypothesis that somatotroph deficiency in hypercortisolemic states reflects ghrelin insufficiency. The exaggerated ACTH and cortisol responsiveness to ghrelin as well as synthetic GHS, is peculiar in hypercortisolism due to pituitary ACTH-dependent Cushing's syndrome $(22-24)$. In fact, the negative feedback effect of glucorticoids on the ACTH response to GHS is still functional in ACTH-independent Cushing's syndrome as well as in normal subjects exposed to glucocorticoids (44). To explain the peculiar ACTH and cortisol hyper-responsiveness that connotes patients with $\mathrm{CD}$, it has been hypothesized that it is likely to reflect the presence of GHS receptors on the ACTH-secreting pituitary tumor (45).

In conclusion, the results of the present study show that hypercortisolism in humans is associated with the peculiar impairment of ghrelin secretion and action. In fact, total ghrelin secretion in CD is not reduced despite increased BMI, insulin and glucose levels, while the GH and ACTH responses to acylated ghrelin are clearly reduced and enhanced, respectively.

\section{Acknowledgements}

This study was supported by Ministero dell'Università e della Ricerca Scientifica (Grant 2004062974), University of Turin and Foundation for the Study of Endocrine and Metabolic Diseases. This study was also partially supported by the EC FP6 grant 'DIABESITY'. The authors wish to thank Prof. F Camanni for his co-operation to the study and Dr A Bertagna, Mrs A Barberis and $\mathrm{M}$ Taliano for their technical assistance.

\section{References}

1 Kojima M, Hosoda H, Date Y, Nakazato M, Matsuo H \& Kangawa K. Ghrelin is a growth hormone-releasing acylated peptide from stomach. Nature $1999 \mathbf{4 0 2} 656-660$.

2 Van der Lely AJ, Tschop M, Heiman ML \& Ghigo E. Biological, physiological, pathophysiological, and pharmacological aspects of ghrelin. Endocrine Reviews 200425 426-457.

3 Papotti M, Ghe C, Cassoni P, Catapano F, Deghenghi R, Ghigo E \& Muccioli G. Growth hormone secretagogue binding sites in peripheral human tissues. Journal of Clinical Endocrinology and Metabolism 200085 3803-3807.

4 Gnanapavan S, Kola B, Bustin SA, Morris DG, McGee P, Fairclough P, Bhattacharya S, Carpenter R, Grossman AB \& Korbonits M. The tissue distribution of the mRNA of ghrelin 
and subtypes of its receptors, GHS-R, in humans. Journal of Clinical Endocrinology and Metabolism 200287 2988-2991.

5 Broglio F, Gottero C, Arvat E \& Ghigo E. Endocrine and non-endocrine actions of ghrelin. Hormone Research 200359 109-117.

6 Horvath TL, Diano S, Sotonyi P, Heiman M \& Tschop M. Minireview: ghrelin and the regulation of energy balance, a hypothalamic perspective. Endocrinology $2001 \mathbf{1 4 2} 4163-4169$.

7 Broglio F, Gottero C, Benso A, Prodam F, Volante M, Destefanis S, Gauna C, Muccioli G, Papotti M, van der Lely AJ \& Ghigo E. Ghrelin and the endocrine pancreas. Endocrine 200322 19-24.

8 Purnell JQ, Weigle DS, Breen P \& Cummings DE. Ghrelin levels correlate with insulin levels, insulin resistance, and high-density lipoprotein cholesterol, but not with gender, menopausal status, or cortisol levels in humans. Journal of Clinical Endocrinology and Metabolism 200388 5747-5752.

9 Tolle V, Bassant MH, Zizzari P, Poindessous-Jazat F, Tomasetto C, Epelbaum J \& Bluet-Pajot MT. Ultradian rhythmicity of ghrelin secretion in relation with $\mathrm{GH}$, feeding behavior, and sleep-wake patterns in rats. Endocrinology 2002143 1353-1361.

10 Cummings DE, Purnell JQ, Frayo RS, Schmidova K, Wisse BE \& Weigle DS. A preprandial rise in plasma ghrelin levels suggests a role in meal initiation in humans. Diabetes $2001501714-1719$.

11 Broglio F, Koetsveld PP, Benso A, Gottero C, Prodam F, Papotti M, Muccioli G, Gauna C, Hofland L, Deghenghi R, Arvat E, Van Der Lely AJ \& Ghigo E. Ghrelin secretion is inhibited by either somatostatin or cortistatin in humans. Journal of Clinical Endocrinology and Metabolism 200287 4829-4832.

12 Saad MF, Bernaba B, Hwu CM, Jinagouda S, Fahmi S, Kogosov E \& Boyadjian R. Insulin regulates plasma ghrelin concentration. Journal of Clinical Endocrinology and Metabolism $2002873997-4000$.

13 Broglio F, Gottero C, Benso A, Prodam F, Casanueva FF, Dieguez C, van der Lely AJ, Deghenghi R, Arvat E \& Ghigo E. Acetylcholine does not play a major role in mediating the endocrine responses to ghrelin, a natural ligand of the GH secretagogue receptor, in humans. Clinical Endocrinology 200358 92-98.

14 Otto B, Cuntz U, Fruehauf E, Wawarta R, Folwaczny C, Riepl RL, Heiman ML, Lehnert P, Fichter M \& Tschop M. Weight gain decreases elevated plasma ghrelin concentrations of patients with anorexia nervosa. European Journal of Endocrinology 2001 $145669-673$.

15 Shiiya T, Nakazato M, Mizuta M, Date Y, Mondal MS, Tanaka M, Nozoe S, Hosoda H, Kangawa K \& Matsukura S. Plasma ghrelin levels in lean and obese humans and the effect of glucose on ghrelin secretion. Journal of Clinical Endocrinology and Metabolism 2002 $87240-244$.

16 Hansen TK, Dall R, Hosoda H, Kojima M, Kangawa K, Christiansen JS \& Jorgensen JO. Weight loss increases circulating levels of ghrelin in human obesity. Clinical Endocrinology 200256 203-206.

17 Tschop M, Weyer C, Tataranni AP, Devanarayan V, Ravussin E \& Heiman ML. Circulating ghrelin levels are decreased in human obesity. Diabetes 200150 707-709.

18 Broglio F, Gianotti L, Destefanis S, Fassino S, Abbate Daga G, Mondelli V, Lanfranco F, Gottero C, Gauna C, Hofland L, Van der Lely AJ \& Ghigo E. The endocrine response to acute ghrelin administration is blunted in patients with anorexia nervosa, a ghrelin hypersecretory state. Clinical Endocrinology 200460 $592-599$.

19 Leidy HJ, Gardner JK, Frye BR, Snook ML, Schuchert MK, Richard EL \& Williams NI. Circulating ghrelin is sensitive to changes in body weight during a diet and exercise program in normal-weight young women. Journal of Clinical Endocrinology and Metabolism 200489 2659-2664.

20 McLaughlin T, Abbasi F, Lamendola C, Frayo RS \& Cummings DE. Plasma ghrelin concentrations are decreased in insulin-resistant obese adults relative to equally obese insulin-sensitive controls. Journal of Clinical Endocrinology and Metabolism $2004 \mathbf{8 9}$ $1630-1635$.

21 Arnaldi G, Angeli A, Atkinson AB, Bertagna X, Cavagnini F, Chrousos GP, Fava GA, Findling JW, Gaillard RC, Grossman AB,
Kola B, Lacroix A, Mancini T, Mantero F, Newell-Price J, Nieman LK, Sonino N, Vance ML, Giustina A \& Boscaro M. Diagnosis and complications of Cushing's syndrome: a consensus statement. Journal of Clinical Endocrinology and Metabolism 2003 88 5593-5602.

22 Ghigo E, Arvat E, Ramunni J, Colao A, Gianotti L, Deghenghi R, Lombardi G \& Camanni F. Adrenocorticotropin- and cortisolreleasing effect of hexarelin, a synthetic growth hormone-releasing peptide, in normal subjects and patients with Cushing's syndrome. Journal of Clinical Endocrinology and Metabolism 199782 2439-2944.

23 Arvat E, Giordano R, Ramunni J, Arnaldi G, Colao A, Deghenghi R, Lombardi G, Mantero F, Camanni F \& Ghigo E. Adrenocorticotropin and cortisol hyperresponsiveness to hexarelin in patients with Cushing's disease bearing a pituitary microadenoma, but not in those with macroadenoma. Journal of Clinical Endocrinology and Metabolism 199883 4207-4211.

24 Leal-Cerro A, Torres E, Soto A, Dios E, Deghenghi R, Arvat E, Ghigo E, Dieguez C \& Casanueva FF. Ghrelin is no longer able to stimulate growth hormone secretion in patients with Cushing's sindrome but instead induces exaggerated corticotropin and cortisol responses. Neuroendocrinology 200276 390-396.

25 Otto B, Tschop M, Heldwein W, Pfeiffer AF \& Diederich S. Endogenous and exogenous glucocorticoids decrease plasma ghrelin in humans. European Journal of Endocrinology 2004151 113-117.

26 Libe R, Morpurgo PS, Cappiello V, Maffini A, Bondioni S, Locatelli M, Zavanone M, Beck-Peccoz P \& Spada A. Ghrelin and adiponectin in patients with Cushing's disease before and after successful trans-sphenoidal surgery. Clinical Endocrinology $20056230-36$.

27 Pasquali R, Vicennati V \& Gambineri A. Adrenal and gonadal function in obesity. Journal of Endocrinological Invesigation 2002 25 893-898.

28 Lucidi P, Murdolo G, Di Loreto C, De Cicco A, Parlanti N. Fanelli C, Santeusanio F, Bolli GB \& De Feo P. Ghrelin is not necessary for adequate hormonal counterregulation of insulin-induced hypoglycemia. Diabetes $2002512911-2914$.

29 Mohlig M, Spranger J, Otto B, Ristow M, Tschop M \& Pfeiffer AF. Euglycemic hyperinsulinemia, but not lipid infusion, decreases circulating ghrelin levels in humans. Journal of Endocrinological Investigation 200225 RC36-RC38.

30 Broglio F, Prodam F, Gottero C, Destefanis S, Me E, Riganti F, Giordano R, Picu A, Balbo M, Van der Lely AJ, Ghigo E \& Arvat E. Ghrelin does not mediate the somatotroph and corticotroph responses to the stimulatory effect of glucagon or insulininduced hypoglycaemia in humans. Clinical Endocrinology 2004 $60699-704$.

31 Nakagawa E, Nagaya N, Okumura H, Enomoto M, Oya H, Ono F, Hosoda H, Kojima M \& Kangawa K. Hyperglycaemia suppresses the secretion of ghrelin, a novel growth-hormonereleasing peptide: responses to the intravenous and oral administration of glucose. Clinical Science 2002103 325-328.

32 Broglio F, Gottero C, Benso A, Prodam F, Destefanis S, Gauna C, Maccario M, Deghenghi R, van der Lely AJ \& Ghigo E. Effects of ghrelin on the insulin and glycemic responses to glucose, arginine, or free fatty acids load in humans. Journal of Clinical Endocrinology and Metabolism $2003 \mathbf{8 8} 4268-4272$.

33 Murdolo G, Lucidi P, Di Loreto C, Parlanti N, De Cicco A, Fatone C, Fanelli CG, Bolli GB, Santeusanio F \& De Feo P. Insulin is required for prandial ghrelin suppression in humans. Diabetes 200352 2923-2927.

34 Poykko SM, Kellokoski E, Horkko S, Kauma H, Kesaniemi YA \& Ukkola O. Low plasma ghrelin is associated with insulin resistance, hypertension, and the prevalence of type 2 diabetes. Diabetes $2003522546-2553$.

35 Holdstock C, Ludvigsson J \& Karlsson FA. Abnormal ghrelin secretion in new onset childhood Type 1 diabetes. Diabetologia 200447 150-151. 
36 Pagotto U, Gambineri A, Vicennati V, Heiman ML, Tschop M \& Pasquali R. Plasma ghrelin, obesity, and the polycystic ovary syndrome: correlation with insulin resistance and androgen levels. Journal of Clinical Endocrinology and Metabolism $2002 \mathbf{8 7}$ 5625-5629.

37 Pagotto U, Gambineri A, Pelusi C, Genghini S, Cacciari M, Otto B, Castaneda T, Tschop M \& Pasquali R. Testosterone replacement therapy restores normal ghrelin in hypogonadal men. Journal of Clinical Endocrinology and Metabolism $2003884139-4143$.

38 Gualillo O, Caminos JE, Kojima M, Kangawa K, Arvat E, Ghigo E, Casanueva FF \& Dieguez C. Gender and gonadal influences on ghrelin mRNA levels in rat stomach. European Journal of Endocrinolology $2001 \mathbf{1 4 4} 687-690$.

39 Caminos JE, Nogueiras R, Blanco M, Seoane LM, Bravo S, Alvarez CV, Garcia-Caballero T, Casanueva FF \& Dieguez C. Cellular distribution and regulation of ghrelin messenger ribonucleic acid in the rat pituitary gland. Endocrinology $2003 \mathbf{1 4 4}$ 5089-5097.

40 Broglio F, Arvat E, Benso A, Gottero C, Muccioli G, Papotti M, van der Lely AJ, Deghenghi R \& Ghigo E. Ghrelin, a natural GH secretagogue produced by the stomach, induces hyperglycemia and reduces insulin secretion in humans. Journal of Clinical Endocrinology and Metabolism 200186 5083-5086.

41 Arosio M, Ronchi CL, Gebbia C, Capiello V, Beck-Peccoz P \& Seracchi M. Stimulatory effects of ghrelin on circulating somato- statin and pancreatic polypeptide levels. Journal of Clinical Endocrinology and Metabolism $2003 \mathbf{8 8} 701-704$.

42 Casanueva FF, Burguera B, Muruais C \& Dieguez C. Acute administration of corticoids: A new and peculiar stimulus of growth hormone secretion in man. Journal of Clinical Endocrinology and Metabolism 199070 234-237.

43 Magiakou MA, Mastorakos G, Gomez MT, Rose SR \& Chrousos GP. Suppressed spontaneous and stimulated growth hormone secretion in patients with Cushing's disease before and after surgical cure. Journal of Clinical Endocrinology and Metabolism 1997 78 131-137.

44 Arvat E, Maccagno B, Ramunni J, Di Vito L, Gianotti L, Broglio F, Benso A, Deghenghi R, Camanni F \& Ghigo E. Effects of dexamethasone and alprazolam, a benzodiazepine, on the stimulatory effect of hexarelin, a synthetic GHRP, on ACTH, cortisol and GH secretion in humans. Neuroendocrinology 199867 310-316.

45 Korbonits M, Bustin SA, Kojima M, Jordan S, Adams EF, Lowe DG Kangawa K \& Grossman AB. The expression of the growth hormone secretagogue receptor ligand ghrelin in normal and abnormal human pituitary and other neuroendocrine tumors. Journal of Clinical Endocrinology and Metabolism $200186881-887$.

Received 25 May 2005

Accepted 13 July 2005 